\title{
Antibacterial effect of an extract of the endophytic fungus Alternaria alternata and its cytotoxic activity on MCF-7 and MDA MB-231 tumour cell lines
}

\author{
U.S. EZHIL ARIVUDAINAMBI ${ }^{1}$, ANANTHA KOTESWARARAO KANUGULA², SRIGIRIDHAR \\ KOTAMRAJU ${ }^{2}$, CHANDRAN KARUNAKARAN ${ }^{1}$ and AYYAPPAN RAJENDRAN ${ }^{3}$
}

\author{
${ }^{1}$ Department of Chemistry, Biomedical Research Laboratory, Virudhunagar Hindu Nadar's \\ Senthikumara Nadar (VHNSN) College, Virudhunagar - 626 001, India \\ ${ }^{2}$ Center for Chemical Biology, Indian Institute of Chemical Technology, \\ Hyderabad-500 607, India \\ ${ }^{3}$ Department of Botany, Biomedical Research Laboratory, \\ VHNSN College, Virudhunagar - 626001 , India
}

Corresponding author: U.S. Ezhil Arivudainambi, usean84@yahoo.co.in

(Received on 23 April 2013; Accepted on 6 May 2014)

\begin{abstract}
There is a growing need for new and effective antimicrobial agents to treat life-threatening diseases. Fungal endophytes are receiving increasing attention by natural product chemists due to the diverse and structurally unprecedented compounds, which make them interesting candidates for drug discovery. The present study evaluates the antibacterial activity of ethyl acetate extract of the endophytic fungus Alternaria alternata VN3 on multi-resistant clinical strains of Staphylococcus aureus and Pseudomonas aeruginosa, as well as its cytotoxicity on MCF-7 and MDA MB-231 tumour cell lines of breast cancer. The maximum inhibition zone of $21.4 \pm 0.07 \mathrm{~mm}$ and $21.5 \pm 0.25 \mathrm{~mm}$ was observed for $S$. aureus strain 10 and $P$. aeruginosa strain 2 , respectively. The ethyl acetate extract showed minimal inhibitory concentration ranging from 100 to $900 \mu \mathrm{g} / \mathrm{ml}$ for $S$. aureus and P. aeruginosa. Further, the ethyl acetate extract of $A$. alternata $\mathrm{VN} 3$ exhibited moderate anticancer activity against MCF-7 and MDA MB-231 cell lines. At $30 \mu \mathrm{g} / \mathrm{ml}$ the cell viability was decreased to $75.5 \%$ and $71.8 \%$ for MCF-7 and MDA MB-231 cells, respectively. These results clearly indicate that the metabolites of $A$. alternata $\mathrm{VN} 3$ are a potential source for production of new drugs.
\end{abstract}

Keywords: endophytic fungus, Alternaria alternata, Staphylococcus aureus, Pseudomonas aeruginosa, anticancer activity, antibacterial activity

\section{INTRODUCTION}

The treatment of bacterial infections is increasingly complicated by the ability of bacteria to develop resistance to antimicrobial agents (TENOVER 2006). There is a growing need for new and effective antibiotic agents due to the emergence of life- 
threatening, multidrug-resistant (MDR) bacterial infections (WEIGHT 2007; DeMAIN \& SANCHEZ 2009). Staphylococcus aureus is a major pathogen causing a diversity of infections, including bacteraemia, pneumonia, skin, soft tissue, and osteo-articular infections (Lowy 1998). Resistance of $S$. aureus, especially methicillin-resistant $S$. aureus (MRSA), continues to be a problem for clinicians worldwide. The growing prevalence of MRSA as a cause of these infections has increased the use of the glycopeptide antibiotic vancomycin over the past 3 decades (NNIS 2002).

MRSA is one of the most important nosocomial pathogens worldwide, but recently it is increasingly identified as the aetiological agent of infections acquired in the community. Molecular epidemiological studies indicate that community-associated (CA)-MRSA and healthcare-associated (HA)-MRSA may have distinctive phenotypic and genetic features (Mammina et al. 2012). These days, MRSA infections acquired outside of the hospital setting have been increasingly reported. The resistance of MRSA to various antimicrobials is globally increasing at an alarming rate. As a result, treatment of MRSA infections has become more challenging. This is a disturbing revelation and a major concern among health care professionals.

Over the past few years, a notable increase in antibiotic resistance among Gramnegative bacteria recovered from hospitalized patients has been reported, especially for critically ill patients (FRIDKIN \& GAYNES 1999). Pseudomonas aeruginosa is an invading Gram-negative opportunistic pathogen that causes nosocomial infections and is responsible for 10\% of all hospital-acquired infections (NAGAVENI et al. 2011). The increasing prevalence of nosocomial infections produced by multidrug-resistant (MDR) P. aeruginosa strains, including isolates with resistance to broad-spectrum $\beta$-lactams, aminoglycosides, and fluoroquinolones, severely compromises the selection of appropriate treatment (WANG et al. 2009).

New methods of treatment are needed also in cancer, which is a major killer disease all over the world, as more than 6000000 new cases are reported every year. Cancer still remains one of the most serious health problems, and breast cancer is the second most universal cause of cancer deaths in women (RAVIKUMAR et al. 2010).

Nature is an attractive source of new therapeutic compounds, as a tremendous chemical diversity is found in millions of species of plants, animals, and microorganisms. Plant-derived compounds have played an important role in the development of several clinically useful anti-cancer agents. Bioactive natural compounds produced by endophytes have also been promising potential usefulness in safety and human health concerns, although there is still a significant demand of the drug industry for synthetic products due to economic and time-consuming reasons (STROBEL et al. 2004). Recently, endophytes have been recognized as important sources of a variety of structurally novel and biologically active secondary metabolites, including terpenoids, steroids, alkaloids, and isocoumarin derivatives (YA-TUAN et al. 2010). Endophyte-derived enzymes and drugs find applications in medicine, agriculture, and industry (ZAFERANLOO et al. 2014).

Alternaria spp. are also endophytes and their metabolites exhibit a variety of biological activities, such as phytotoxic, cytotoxic, and antimicrobial properties, which have drawn the attention of many chemists, pharmacologists, and plant pathologists in research programs as well as in application studies (BRASE et al. 2009; TsUGE et al. 
2013). In recent years, more and more metabolites with bioactivities from Alternaria fungi have been isolated and structurally characterized. In this study, the endophytic fungal extract of $A$. alternata $\mathrm{VN} 3$ was screened for its antibacterial and anticancer activity against multidrug-resistant Staphylococcus aureus, Pseudomonas aerugino$s a$, and human breast cancer cells.

\section{MATERIALS AND METHODS}

\section{Isolation of endophytic fungi}

Healthy leaves of the medicinal plant Vitex negundo L. were collected in the Botanical Garden of our college in Virudhunagar. All the leaf samples were washed twice in distilled water and then surface-sterilized by immersion for $1 \mathrm{~min}$ in $70 \%$ $(\mathrm{v} / \mathrm{v})$ ethanol, $4 \mathrm{~min}$ in sodium hypochlorite [3\% (v/v) available chlorine], $30 \mathrm{~s}$ in $70 \%(\mathrm{v} / \mathrm{v})$ ethanol, and next washed 3 times in sterilized distilled water for $1 \mathrm{~min}$ each time. After surface sterilization, the samples were cut into 5-7-mm pieces and aseptically transferred to Petri plates containing malt extract agar with $50 \mu \mathrm{g} / \mathrm{ml}$ of streptomycin to suppress bacterial growth. These Petri plates were incubated at $30^{\circ} \mathrm{C}$ with normal photoperiod ( $12 \mathrm{~h}$ light and $12 \mathrm{~h}$ dark).The plates were examined daily for up to one month for the development of fungal colonies growing out from the leaf segments (ARNOLD et al. 2000). The fungi growing out from the leaf tissue were subsequently transferred onto fresh malt extract agar plates without antibiotics. The identification of endophytic fungal strains was confirmed by morphological and $18 \mathrm{~S}$ rRNA sequence analysis (AltsChUl et al. 1990).

\section{S rRNA gene sequencing}

To verify identification of the fungal strains, total genomic DNA was extracted using the method of DoyLe \& Doyle (1987). The ITS1 5.8s and ITS2 regions of nrDNA were amplified using the primers ITS1 and ITS2 (WhITE et al. 1990) and the $18 \mathrm{~S}$ region was amplified using the 5'-TCCGTAGGTGAACCTGCGG-3' and 5'-TCCTCCGCTTATTGATATGC-3' primers (WhITE et al. 1990). Isolates of $18 \mathrm{~s}$ rRNA fungal sequences obtained were submitted to GenBank (NCBI, USA) (accession number JF 795288). The $18 \mathrm{~S}$ rRNA gene sequencing was done at Synergy Scientific Services, Chennai, India.

\section{Extraction of bioactive compounds}

The selected endophytic fungal isolates of Alternaria alternata were grown on potato dextrose agar at $30^{\circ} \mathrm{C}$ for 5 days. Three pieces $\left(0.5 \times 0.5 \mathrm{~cm}^{2}\right)$ of actively growing mycelial agar plugs were inoculated into $500-\mathrm{ml}$ Erlenmeyer flasks containing $200 \mathrm{ml}$ of potato dextrose broth and incubated at $30^{\circ} \mathrm{C}$ for 3 weeks under stable conditions. After the incubation period, fungal mycelium was separated from the culture medium by vacuum filtration through Whatman no. 1 filter paper. The dried mycelia and culture filtrate were extracted 3 times with ethyl acetate alone. The solvent was removed by evaporation under reduced pressure at $50^{\circ} \mathrm{C}$, using rotary vacuum evaporator. After evaporation, the dried fungal extract was dissolved in $10 \%$ dimethyl sulphoxide (DMSO) and we studied the antibacterial and anticancer activity. 


\section{Determination of the sensitivity of pathogenic bacteria}

The Kirby-Bauer disc diffusion test was used to determine the antibiotic resistance of clinical strains of Staphylococcus aureus and Pseudomonas aeruginosa. The strains of $S$. aureus (1-10) and P. aeruginosa (1-8) were obtained from Bose Clinical Laboratory and X-ray (Madurai, Tamilnadu, India). The nutrient broth was prepared and well-isolated colonies of the same type from a culture agar plate were inoculated into it. The culture broth was incubated at $37^{\circ} \mathrm{C}$ until the culture equalled $0.5 \mathrm{McFar}-$ land standards. A McFarland 0.5 turbidity standard corresponded to an inoculum of $1 \times 10^{8} \mathrm{CFU} / \mathrm{ml}$ (ACAR \& GoldSTEIN 1991). Usually 2-8 h was required to reach this standard. A sterile cotton swab was dipped in the inoculum and the excess was removed by rotating the swab several times against the inside wall of the tube above the level of the fluid. The surface of this plate was inoculated by streaking the swab over the surface. Antibiotic discs with penicillin (10 units/disc), methicillin (5 $\mu \mathrm{g} / \mathrm{disc})$, and vancomycin $(30 \mu \mathrm{g} / \mathrm{disc})$, were used for $S$. aureus. Ciprofloxacin $(5 \mu \mathrm{g} / \mathrm{disc})$, cefotaxime $(30 \mu \mathrm{g} / \mathrm{disc})$, ofloxacin $(5 \mu \mathrm{g} / \mathrm{disc})$, and amikacin $(30 \mu \mathrm{g} / \mathrm{disc})$ were used for $P$. aeruginosa strains. Ethyl acetate extract $(100 \mu \mathrm{g} / \mathrm{ml})$ of Alternaria alternata was used to study the antibacterial activity against the $S$. aureus and $P$. aeruginosa stains. In the control, the DMSO solvent alone was used $(10 \mu \mathrm{l})$. To ensure complete contact of the discs with the agar surface, the discs were pressed down slightly. The experiments were carried out in triplicates. Inoculated plates were inverted and incubated at $37^{\circ} \mathrm{C}$ for $18 \mathrm{~h}$. After the incubation period, the diameter of the inhibition zone was measured and results were interpreted according to the standards of the Clinical Laboratory Standards Institute (CLSI 2005).

\section{Determination of minimum inhibitory concentration (MIC)}

MIC of the ethyl acetate extract was determined based on a broth micro-dilution method in a 96-well microplate (AL-BAYATI 2008). Briefly, the clinical strains of Staphylococcus aureus (1-10) and Pseudomonas aeruginosa (1-8) were cultured overnight at $37^{\circ} \mathrm{C}$ on Muller Hinton (MH) broth (Himedia Laboratories, Mumbai, India) and adjusted to a final density of $10^{8}$ colony-forming units (CFU)/ml by 0.5 McFarland standards. The crude ethyl acetate extract $(1 \mathrm{mg} / \mathrm{ml})$ was dissolved in $10 \%$ DMSO. In 96-well plates, each well had $90 \mu \mathrm{l}$ of $\mathrm{MH}$ broth supplemented with $2 \% \mathrm{NaCl}, 10 \mu \mathrm{l}$ of bacterial inoculum, and $10 \mu \mathrm{l}$ of different concentrations of the fungal extract. The plate was incubated at $37^{\circ} \mathrm{C}$ for $18 \mathrm{~h}$. After incubation, the bacterial growth was visually inspected and the lowest concentration of fungal extract at which no observable bacterial growth or turbidity was observed, was considered as the MIC value. Experiments were performed independently 3 times and each sample was assayed in duplicate.

\section{Cell culture}

Human breast cancer cells MCF-7 and MDA MB-231 were obtained from the American Type Culture Collection (Rockville, MD) and grown in minimum essential eagle medium (MEM) supplemented with $10 \%$ foetal bovine serum, penicillin (100 $\mathrm{U} / \mathrm{ml})$, and streptomycin $(100 \mathrm{mg} / \mathrm{ml})$ in 24-well tissue culture plates (Costar, Cambridge, MA). 


\section{MTT reduction cytotoxic assay}

A yellow tetrazole, 3-(4,5-dimethylthiazol-2-yl)-2,5-diphenyltetrazolium bromide (MTT), was taken up by cells and was reduced to a coloured formazan product that could be detected by spectrophotometry $\left(\mathrm{k}_{\max }=562 \mathrm{~nm}\right)$. Reduction of MTT was dependent on the mitochondrial respiratory function, and thus it reflected the relative number of viable cells in the culture. MCF-7 and MDA MB-231 cells were treated with various concentrations $(0,10,20$ and $30 \mu \mathrm{g} / \mathrm{ml})$ of the ethyl acetate extract of Alternaria alternata VN3 for $48 \mathrm{~h}$. DMSO alone was used in the control. At the end of the treatments, media were aspirated, the cells were washed with DPBS buffer, and again incubated with $5 \mathrm{mg} / \mathrm{ml}$ of MTT for $1 \mathrm{~h}$ at $37^{\circ} \mathrm{C}$. DMSO was used to dissolve the formazan. The absorbance was measured at $562 \mathrm{~nm}$, using an automated TECAN multimode reader. The results represented are from 3 independent experiments.

\section{RESULTS AND DISCUSSION}

In total, 30 endophytic fungi were isolated from the medicinal plant Vitex negundo. Among them, Alternaria alternata was selected, based on its antimicrobial and anticancer activity. The fungus grows rapidly on potato dextrose agar and the colony was flat, downy to cottony, and eventually was covered by greyish, short, aerial hyphae. The reverse side was typically brown to black, due to pigment production. Alternaria is septate, with dark hyphae. They bear simple or branched large conidia $(8-16 \mu \mathrm{m} \times 23-50 \mu \mathrm{m})$, which have both transverse and longitudinal septa. These conidia may be observed singly or in acropetal chains and may produce germ tubes. They were ovoid to obclavate, darkly pigmented muriform, smooth or roughened. Morphological characteristics allowed the identification of the endophytic fungus as $A$. alternata, which was confirmed by the sequence of its $18 \mathrm{~S}$ rRNA gene that gave a $95 \%$ sequence similarity to those accessible at the BLASTN of $A$. alternata. The endophytic fungus was designated as A. alternata VN3. The fungal sequence was deposited as GenBank accession no. JF 795288.

The antibiotic activity of Staphylococcus aureus strains (1-10) was determined using commercial antibiotics. All the $S$. aureus strains were slightly or moderately inhibited by penicillin. Strain 7 was moderately inhibited by methicillin, in contrast to all the other strains (1-6 and 8-10), with low inhibition by methicillin. Strains 6, 8 , and 9 were moderately sensitive to vancomycin, whereas the other strains $(1-5,7$, and 10) were highly inhibited by vancomycin. The ethyl acetate extract of Alternaria alternata VN3 showed effective antibacterial activity against $S$. aureus strains (1-10). At a concentration of $100 \mu \mathrm{g} / \mathrm{ml}$, a maximum inhibition zone of $21.4 \pm 0.07 \mathrm{~mm}$ was observed for $S$. aureus strain 10 and a minimum inhibition zone of $12.6 \pm 0.04 \mathrm{~mm}$ for strain 8 (Table 1).

To determine the antibacterial profile of Pseudomonas aeruginosa strains, ciprofloxacin, cefotaxime, ofloxacin, and amikacin were used. Strains 1 and 3 were moderately sensitive, whereas strains 2,5 , and 6 reacted more strongly to the 4 antibiotics. Strain 4 reacted strongly to ciprofloxacin and ofloxacin, whereas moderately to cefotaxime and amikacin. Strain 7 was highly inhibited by cefotaxime and only slightly or moderately by all the other antibiotics. Ciprofloxacin was highly effec- 
Table 1. Antibacterial activity and minimum inhibitory concentration (MIC) of ethyl acetate extracts of Alternaria alternata VN3 against Staphylococcus aureus strains

\begin{tabular}{cccccc}
\hline \multirow{2}{*}{$\begin{array}{c}\text { S. aureus } \\
\text { strains }\end{array}$} & $\begin{array}{c}\text { Penicillin } \\
(\mathbf{1 0} \text { unit/disc) }\end{array}$ & $\begin{array}{c}\text { Methicillin } \\
\mathbf{( 1 0} \boldsymbol{\mu g} / \mathbf{d i s c})\end{array}$ & $\begin{array}{c}\text { Vancomycin } \\
\mathbf{( 3 0} \boldsymbol{\mu g} / \mathbf{d i s c})\end{array}$ & $\begin{array}{c}\text { Ethyl acetate } \\
\mathbf{e x t r a c t} \\
(\mathbf{1 0 0} \boldsymbol{\mu g} / \mathbf{m l})\end{array}$ & $\begin{array}{c}\text { MIC } \\
(\boldsymbol{\mu g} / \mathbf{m l})\end{array}$ \\
\hline 1 & $12.8 \pm 0.15$ & $10.8 \pm 0.14$ & $16.5 \pm 0.08$ & $20.4 \pm 0.04$ & 200 \\
2 & $12.8 \pm 0.14$ & $11.2 \pm 0.31$ & $15.4 \pm 0.28$ & $18.2 \pm 0.25$ & 300 \\
3 & $14.2 \pm 0.28$ & $12.1 \pm 0.16$ & $16.0 \pm 0.22$ & $17.6 \pm 0.31$ & 500 \\
4 & $11.5 \pm 0.35$ & $10.2 \pm 0.31$ & $17.2 \pm 0.14$ & $13.5 \pm 0.14$ & 600 \\
5 & $10.8 \pm 0.14$ & $8.9 \pm 0.22$ & $18.5 \pm 0.28$ & $18.6 \pm 0.35$ & 300 \\
6 & $10.3 \pm 0.15$ & $9.5 \pm 0.35$ & $12.4 \pm 0.35$ & $17.4 \pm 0.15$ & 600 \\
7 & $13.8 \pm 0.16$ & $15.5 \pm 0.07$ & $16.9 \pm 0.14$ & $15.8 \pm 0.22$ & 400 \\
8 & $10.5 \pm 0.23$ & $8.8 \pm 0.14$ & $13.5 \pm 0.21$ & $12.6 \pm 0.04$ & 900 \\
9 & $14.0 \pm 0.21$ & $12.2 \pm 0.10$ & $14.8 \pm 0.22$ & $16.5 \pm 0.35$ & 800 \\
10 & $14.9 \pm 0.1$ & $8.9 \pm 0.18$ & $17.4 \pm 0.35$ & $21.4 \pm 0.07$ & 100 \\
\hline
\end{tabular}

tive, while the other antibiotics were moderately effective for $P$. aeruginosa strain 8 . The ethyl acetate extract showed significant antibacterial activity against clinical strains of $P$. aeruginosa. A maximum inhibition zone of $21.5 \pm 0.25 \mathrm{~mm}$ was observed for $P$. aeruginosa strain 2, while a minimum inhibition zone of $13.8 \pm 0.22 \mathrm{~mm}$, for strain 3 (Table 2).

Similarly, DAMAJAN et al. (2007) reported antibacterial activity of extracts of Amanita virosa (Fr) Bertill (Amanitaceae) and Cortinarius praestans Cordier (Cortinariaceae) against Pseudomonas aeruginosa and Staphylococcus aureus. Xanalteric acids I and II as well as 11 known secondary metabolites were obtained from the endopytic fungus Alternaria sp. isolated from the mangrove plant Sonneratia alba. Xanalteric acids I and II exhibited weak antibacterial activity against multidrug-resistant Staphylococcus aureus, whereas alternusin displayed broad antimicrobial activity against several additional multidrug-resistant bacterial and fungal strains (KJER et al. 2009).

The lowest concentration of the fungal extract at which no growth of microorganism observed upon visual observation after incubation at $37^{\circ} \mathrm{C}$ for $18 \mathrm{~h}$ was considered as the MIC value. Pellets formed at the bottom of wells were considered bacterial growth even if the wells were clear of turbidity. The MIC value ranged from 
Table 2. Antibacterial activity and minimum inhibitory concentration (MIC) of ethyl acetate extracts of Alternaria alternata VN3 against Pseudomonas aeruginosa strains

\begin{tabular}{|c|c|c|c|c|c|c|}
\hline \multirow[b]{2}{*}{$\begin{array}{l}\text { P. aeruginosa } \\
\text { strains }\end{array}$} & \multicolumn{5}{|c|}{ Zone of inhibition (mm) } & \multirow[b]{2}{*}{$\begin{array}{c}\mathrm{MIC} \\
(\mu \mathrm{g} / \mathrm{ml})\end{array}$} \\
\hline & $\begin{array}{c}\text { CI } \\
(5 \mu \mathrm{g} / \mathrm{disc})\end{array}$ & $\begin{array}{l}\mathrm{CE}(30 \mu \mathrm{g} / \\
\text { disc) }\end{array}$ & $\begin{array}{c}\text { OF } \\
(5 \mathrm{~g} / \mathrm{disc})\end{array}$ & $\begin{array}{c}\mathrm{AK} \\
(30 \mu \mathrm{g} / \mathrm{disc})\end{array}$ & $\begin{array}{c}\text { Ethyl acetate } \\
\text { extract } \\
(100 \mu \mathrm{g} / \mathrm{ml})\end{array}$ & \\
\hline 1 & $14.5 \pm 0.4$ & $12.4 \pm 0.4$ & $12.5 \pm 0.35$ & $15.5 \pm 0.17$ & $17.6 \pm 0.31$ & 600 \\
\hline 2 & $21.6 \pm 0.1$ & $23.5 \pm 0.14$ & $20.3 \pm 0.28$ & $20.5 \pm 0.14$ & $21.5 \pm 0.25$ & 200 \\
\hline 3 & $15.4 \pm 0.28$ & $14.9 \pm 0.14$ & $13.5 \pm 0.4$ & $12.9 \pm 0.28$ & $13.8 \pm 0.22$ & 700 \\
\hline 4 & $23.7 \pm 0.23$ & $16.8 \pm 0.1$ & $18.6 \pm 0.31$ & $14.5 \pm 0.31$ & $15.3 \pm 0.14$ & 400 \\
\hline 5 & $24.3 \pm 0.04$ & $24.8 \pm 0.15$ & $19.5 \pm 0.14$ & $19.4 \pm 0.22$ & $20.8 \pm 0.1$ & 200 \\
\hline 6 & $22.3 \pm 0.15$ & $25.4 \pm 0.07$ & $18.4 \pm 0.28$ & $18.8 \pm 0.07$ & $20.3 \pm 0.07$ & 300 \\
\hline 7 & $16.5 \pm 0.22$ & $23.7 \pm 0.18$ & $13.9 \pm 0.4$ & $10.5 \pm 0.28$ & $14.6 \pm 0.22$ & 500 \\
\hline 8 & $18.7 \pm 0.14$ & $16.5 \pm 0.35$ & $16.5 \pm 0.14$ & $14.4 \pm 0.23$ & $18.3 \pm 0.14$ & 500 \\
\hline
\end{tabular}

$\mathrm{CI}=$ ciprofloxacin $; \mathrm{CE}=$ cefotaxime; $\mathrm{OF}=$ ofloxacin $; \mathrm{AK}=$ amikacin.

100 to $900 \mu \mathrm{g} / \mathrm{ml}$ for clinical strains of $S$. aureus. The lowest MIC value of $100 \mu \mathrm{g} /$ $\mathrm{ml}$ was observed for $S$. aureus strain 10 (Table 1). The MIC value ranged from 200 to $700 \mu \mathrm{g} / \mathrm{ml}$ for $P$. aeruginosa strains (1-8). The lowest MIC value of $200 \mu \mathrm{g} / \mathrm{ml}$ was observed for strains 2 and 5 (Table 2).

The recorded MIC values tended to be higher than earlier reported for Alternaria spp. Three new cerebrosides, alternarosides $\mathrm{A}-\mathrm{C}$, and new diketopiperazine alkaloid alternarosin A were isolated from ethyl acetate extract of Alternaria raphani. Alternarosides A-C and alternarosin A showed weak antibacterial activity against $E s$ cherichia coli, Bacillus subtilis, and Candida albicans, with MIC values ranging from 70 to $400 \mu \mathrm{M}$ (WANG et al. 2010). The bioactive compound altechromone was isolated from endophytic fungi from Alternaira brassicicola ML-P08, which displayed antimicrobial activity against B. subtilis, E. coli, Pseudomonas fluorescens, and C. albicans, with MIC values of 3.9, 3.9, 1.8, and $3.9 \mu \mathrm{g} / \mathrm{ml}$, respectively (Gu 2009).

The anticancer activity of the ethyl acetate extract of Alternaria alternata VN3 was also investigated, against the malignant MCF-7 and metastatic MDA MB-231 human breast cancer cell lines for $48 \mathrm{~h}$. The ethyl acetate extract of $A$. alternata VN3 dose dependently $(0-30 \mu \mathrm{g} / \mathrm{ml})$ increased cytotoxicity in both MCF-7 and MDA MB231 breast cancer cells (Figs. 1-2). At $30 \mu \mathrm{g} / \mathrm{ml}$, cell viability decreased to $75.5 \%$ and $71.8 \%$ for MCF-7 and MDA MB-231 cell, respectively. Similarly, LiU et al. (2007) 


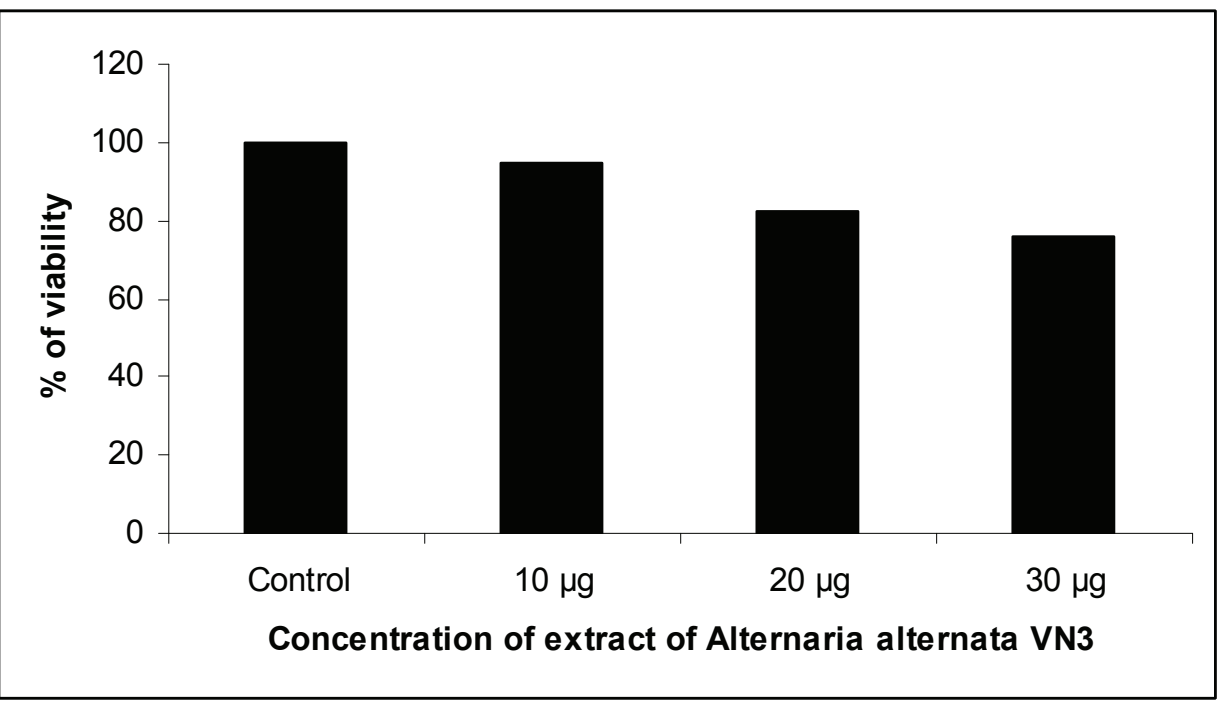

Fig. 1. Anticancer activity of ethyl acetate extract of Alternaria alternata VN3 against MCF-7 cells

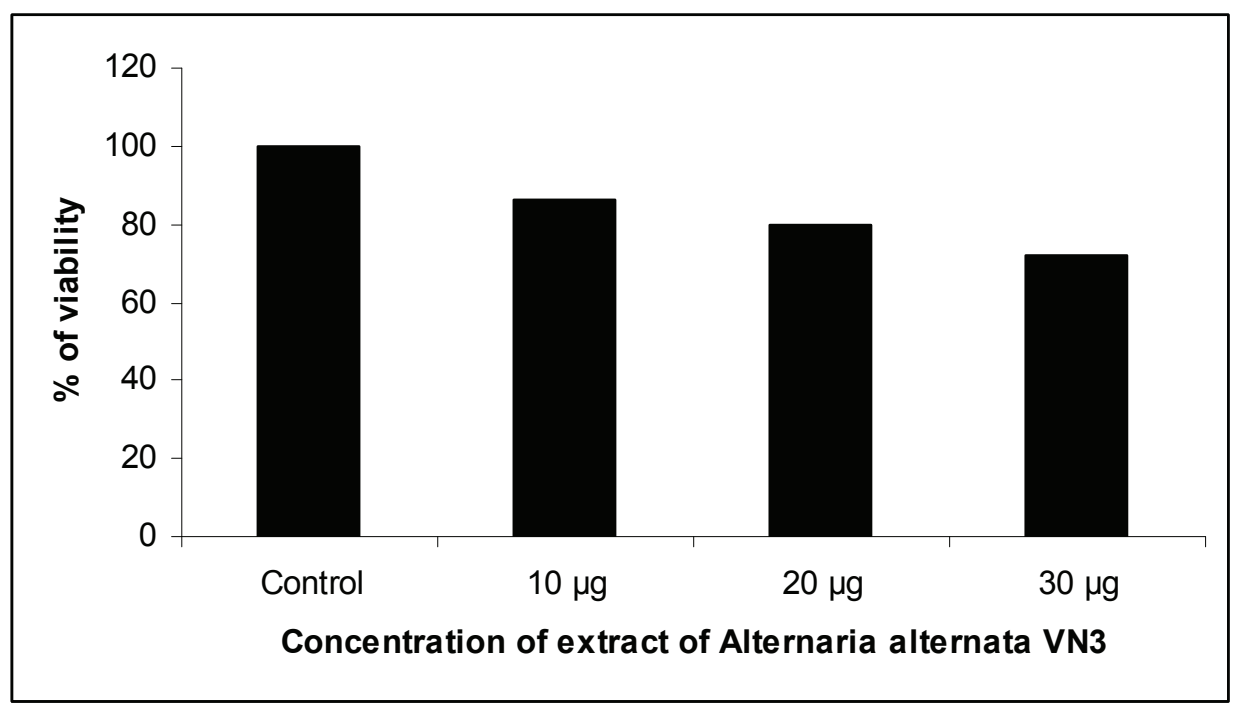

Fig. 2. Anticancer activity of ethyl acetate extract of Alternaria alternata VN3 against MDA MB231 cells 
demonstrated for the first time that alternol, a new compound purified from the fermenting products of A. alternata var. monosporus from the bark of yew (Taxus sp.), was found to inhibit proliferation and induce apoptosis in mouse lymphocyte leukaemia L1210 cells. FERNANDES et al. (2009) studied the antitumour activity of fermentation extract of the endophytic fungus $A$. alternata isolated from Coffea arabica L. At a dilution of $400 \mu \mathrm{g} / \mathrm{ml}$, the extract displayed a cytotoxic activity of approximately $50 \%$ towards HeLa cells in vitro. In comparison, A. alternata VN3 had effective anticancer activity at a lower concentration. The control DMSO had no significant effect on MCF-7 and MDA MB-231 breast cancer cells.

\section{CONCLUSIONS}

The endophytic microorganism Alternaria alternata seems to produce bioactive and probably chemically novel compounds bearing pharmaceutical potential. The ethyl acetate extract of $A$. alternata VN3 had the maximum inhibition zone of $21.4 \pm 0.07 \mathrm{~mm}$ and $21.5 \pm 0.25 \mathrm{~mm}$ for Staphylococcus aureus strain 10 and Pseudomonas aeruginosa strain 2, respectively. Also, A. alternata VN3 showed moderate anticancer activity against MCF-7 and MDA MB-231 cell lines. At $30 \mu \mathrm{g} / \mathrm{ml}$, cell viability was decreased to $75.5 \%$ and $71.8 \%$ for MCF-7 and MDA MB-231 cells, respectively. Our results indicate that the ethyl acetate extract of endophytic fungus A. alternata VN3 is a potential source for production of new metabolites for treatment of drug-resistant bacteria and cancer cell lines. However, further chemical characterization is needed to identify the compounds and their mechanism of action in the endophyte extracts with the observed biological activity against human pathogenic bacteria and cancer cell lines.

Acknowledgments: This work was supported by the University Grants Commission, New Delhi, India [F. No. 35-50/2008 (SR)] and the Managing Board of Virudhunagar Hindu Nadar's Senthikumara Nadar College, Virudhunagar, Tamilnadu, India. Ramanujan fellowship from the Department of Science and Technology, India to SK is greatly acknowledged.

\section{REFERENCES}

Acar J. F, Goldstein F. W. 1991. Disk susceptibility test, Chapter 2. In: Antibiotics in laboratory medicine (LoRIAN V. MD, Ed.), pp. 17-52, $3^{\text {rd }}$ ed., Williams \& Wilkins, Maryland, USA.

Altschul S. F., Gish W., Miller W., Myers E. W., LipMan D. J. 1990. Basic local alignment search tool. J. Mol. Biol. 215: 403-410.

Al-Bayati F. A. 2008. Synergistic antibacterial activity between Thymus vulgaris and Pimpinella anisum essential oils and methanol extracts. J. Ethnopharmacol. 16: 403-406.

Arnold A. E., Maynard Z., Gilbert G., Coley P. D., Kursar T. A. 2000. Are tropical endopytic fungi hyperdiverse? Ecol. Lett. 3: 267-274.

Brase S., Encinas A., Keck J., Nising C. F. 2009. Chemistry and biology of mycotoxins and related fungal metabolites. Chem. Rev. 109: 3903-3990.

[CLSI] Clinical and Laboratory Standards Institute 2005. Performance standards for antimicrobial susceptibility testing fifteenth informational supplement. Document M100-S15, Vol.25, No.1. Clinical and laboratory standards institute, Wayne, $\mathrm{Pa}$. 
Damjan J., Samo K., Maja J., Katja S., Borut S. 2007. Antibacterial activity in higher fungi (Mushrooms) and Endophytic fungi from Slovenia. Pharm. Biol. 45: 700-706.

Demain A. L, Sanchez S. 2009. Microbial drug discovery: 80 years of progress. J. Antibiot. 62: $5-16$.

Doyle J. J., Doyle J. L. 1987. A rapid DNA isolation procedure for small quantities of fresh leaf tissue. Phytochem. Bull. 19: 11-15.

FridKIN S. K., GAYNes R. P. 1999. Antimicrobial resistance in intensive care units. Clin. Chest Med. 20: 303-316.

Fernandes M. R. V., Silva T. A. C., Pfenning L. H., Costa-Neto C. M., Heinrich T. A., Alencar S. M., Lima M. A., Ikegaki M. 2009. Biological activities of the fermentation extract of the endophytic fungus Alternaria alternata isolated from Coffea arabica L. Braz. J. Pharm. Sci. 45: 677-685.

Gu W. 2009. Bioactive metabolites from Alternaria brassicicola ML-P08, an endophytic fungus residing in Malus halliana. World J. Microb. Biotech. 25: 1677-1683.

Kjer J., Wray V., Edrada-Ebel R., Ebel R., Pretsch A., Lin W., Proksch P. 2009. Xanalteric acids I and II and related phenolic compounds from an endophytic Alternaria sp. isolated from the mangrove plant Sonneratia alba. J. Nat. Prod. 72: 2053-2057.

Liu Z., Zhu J., Sun B., Liu S., Geng S., Liu X., Li C. L. 2007. Alternol inhibits proliferation and induces apoptosis in mouse lymphocyte leukemia (L1210) cells. Mol. Cell Biochem. 306: $115-122$.

Lowy F. D. 1998. Staphylococcus aureus infections. New Engl. J. Med. 339: 520-532.

Mammina C., Cala C., Bonura C., Carlo P. D., Aleo A., Fasciana T., Giammanco A. 2012. EPIMRSA Working Group: Polyclonal non multi-resistant Staphylococcus aureus isolates from clinical cases of infection occurring in Palermo, Italy, during a one-year surveillance period. Ann. Clin. Microbiol. Antimicrob. 11: 17.

Nagaveni S., Rajeshwari H., Oli A. K., Patil S. A., Chandrakanth R. K. 2011. Widespread emergence of multidrug resistant Pseudomonas aeruginosa isolated from CSF samples. Indian J. Microbiol. 51: 2-7.

[NNIS] National Nosocomial Infections Surveillance 2002. National Nosocomial Infections Surveillance (NNIS) System report, data summary from January 1992 to June 2002, issued August 2002. Am. J. Infect. Control 30: 458-475.

Ravikumar S., Gnanadesigan M., Thajuddin N., Chakkaravarthi V. S. D., Banerjee B. M. 2010. Anticancer property of sponge associated actinomycetes along Palk Strait. J. Pharm. Res. 3: 2415-2417.

Stroble G., Daisy B., Castillo U., Harper J. 2004. Natural products from endophytic microorganisms. J. Nat. Prod. 67: 257-268.

Tenover F. C. 2006. Antimicrobial Resistance in Bacteria. Am. J. Med. 119: 3-10.

Tsuge T., Harimoto Y., Akimitsu K., Ohtani K., Kodama M., Akagi Y., Egusa M., Yamamoto M., OtANi H. 2013. Host-selective toxins produced by the plant pathogenic fungus Alternaria alternata. FEMS Microbiol. Rev. 37: 44-66.

Wang J., Zhou J. Y., Qu T. T., Shen P., Wei Z. Q. 2010. Molecular epidemiology and mechanisms of carbepenem resistance in Pseudomonas aeruginosa isolates from Chinese hospitals. Int. J. Antimicrob. Ag. 35: 486-491.

Wang W., Wang Y., Tao H., Peng X., Liu P., Zhu W. 2009. Cerebrosides of the halotolerant fungus Alternaria raphani isolated from a sea salt field. J. Nat. Prod. 72: 1695-1698.

White R. L., Burgess D. S., Mandruru M., Bosso J. A. 1996. Comparison of three different in vitro methods of detecting synergy: Time-kill, checkerboard and E-test. Antimicrob. Agents Chemother. 40: 1914-1918.

White T. J., Bruns T. D., Lee S., TAylor J. W. 1990. Amplification and direct sequencing of fungal ribosomal RNA genes for phylogenetics. In: PCR Protocols: a Guide to Methods and Applications (Innis M. A., Gelfand D., Sninsky J. S., White T. J., Eds.), pp. 315-322, Academic, San Diego. 
Wright G. D. 2007. The antibiotic resistome: the nexus of chemical and genetic diversity. Nat. Rev. Microbiol. 5: 175-186.

Ya-Tuan M., Li-Rui Q., Wen-Quan S., An-Ling Z., Jin-Ming G. 2010. Metabolites produced by an endophyte Alternaria alternata isolated from Maytenus hookeri. Chem. Nat. Compd. 46: 3.

Zaferanloo B., Quang T. D., Daumoo S., Ghorbani M. M., Mahon P. J., Palombo E. A. 2014. Optimization of protease production by endophytic fungus, Alternaria alternata isolated from an Australian native plant. World J. Microbiol. Biotechnol. Doi:10.1007/s11274-014-1598-z. 